\title{
Plasma interleukin-2 and a soluble/shed interleukin-2 receptor in serum of patients with Crohn's disease. Effect of cyclosporin
}

\author{
J Brynskov, N Tvede
}

\begin{abstract}
Circulating concentrations of interleukin-2 (IL-2) and a soluble or shed form of the IL-2 receptor (sIL-2R) were determined by enzymelinked immunosorbent assays (ELISA) in 61 patients with chronic active Crohn's disease (CD) initially and during a three month placebo controlled trial of cyclosporin $5-7.5 \mathrm{mg} / \mathrm{kg}$ / day. The baseline median (25-75\% range) plasma IL-2 concentration was $0.6 \mathrm{ng} / \mathrm{ml}$ $(0.3-2.85 \mathrm{ng} / \mathrm{ml})$ in patients who did not receive prednisolone, $0.5 \mathrm{ng} / \mathrm{ml}(0.23-3.4 \mathrm{ng} / \mathrm{ml})$ in patients who did (not significant), and $0 \mathrm{ng} / \mathrm{ml}$ $(0-0.07 \mathrm{ng} / \mathrm{ml})$ in control subjects $(p<0.00001)$. The corresponding median serum sIL $-2 R$ concentrations were $747 \mathrm{U} / \mathrm{ml}(580-1287 \mathrm{U} / \mathrm{ml})$, $540 \mathrm{U} / \mathrm{ml}(422-616 \mathrm{U} / \mathrm{ml})$ respectively in CD patients $(p=0.006)$ and $320 \mathrm{U} / \mathrm{ml}(268-406 \mathrm{U} /$ $\mathrm{ml})$ in control subjects $(\mathrm{p}<0.00001)$. Increased concentrations of plasma $\mathbf{I L - 2}$ and serum sIL-2R were seen in $66 \%$ and $81 \%$ of the patients, respectively. A fall in serum sIL-2R was only seen in patients who improved with cyclosporin treatment $(p=0.006)$. At month 3 the median serum sIL-2R concentration was $440 \mathrm{U} / \mathrm{ml}(400-668 \mathrm{U} / \mathrm{ml}) v 801 \mathrm{U} / \mathrm{ml}$ (534-1067 $\mathrm{U} / \mathrm{ml}$ ) in patients not responding to cyclosporin ( $p=0.003)$. No changes occurred in the placebo group. These results suggest that the IL-2 dependent pathway of immune activation is upregulated in vivo in CD and that cyclosporin may interfere with this process.
\end{abstract}

Interleukin-2 (IL-2) functions as an obligatory signal for $\mathrm{T}$ cell growth, and this ligand effect is mediated through a specific $T$ cell surface receptor (IL-2R). IL-2 production and IL-2R expression are determined by antigen recognition or mitogen stimulation. ${ }^{1}$ In vitro studies on isolated mononuclear cells, using bioassays, suggest that the production of IL-2 may be impaired in active Crohn's disease (CD),${ }^{24}$ even though $\mathrm{T}$ cells appear to be activated in this disease. ${ }^{5}$ Accordingly, we have recently shown that cyclosporin, a potent inhibitor of IL-2 production by $\mathrm{T}$ cells, ${ }^{6}$ has a beneficial therapeutic effect on chronic active $C D$.

Specific enzyme-linked immunosorbent assays (ELISAs) are now available for the determination of IL-2 and a soluble/shed form of IL-2R (sIL-2R) in vivo, using plasma or serum. ${ }^{8}$ Clinical studies have shown that conditions characterised by enhanced $\mathrm{T}$ cell mediated immunity in vivo, such as transplant rejection, are associated with high concentrations of $\mathrm{IL}-2$ or sIL-2R, or both. ${ }^{9-11}$ Therefore, it seemed of interest to determine circulating IL-2 and sIL-2R concentrations as measures of continuing $\mathrm{T}$ cell activation in CD. Furthermore, in longitudinal studies we investigated whether these measurements might be a means of monitoring cyclosporin treatment.

\section{Methods}

Serial serum and heparin-stabilised plasma samples were collected at five of six centres participating in a three-month placebo controlled trial of cyclosporin $5-7 \cdot 5 \mathrm{mg} / \mathrm{kg} /$ day in patients with chronic active CD. ${ }^{7}$ Serum samples were available for 59 of 63 eligible patients and plasma samples for 61 patients. Single samples were missing at baseline and later. There were 22 men and 39 women, with a median age of 33 years (range 16-68 years) and a median disease duration of five years (range 1-22 years). Twenty patients (33\%) had ileal disease, $10(16 \%)$ colonic disease, and $31(51 \%)$ ileocolic disease. Eighteen patients $(30 \%)$ received fixed doses of prednisolone during the study (median $10 \mathrm{mg} /$ day, range $5-20 \mathrm{mg} /$ day) and 41 patients $(67 \%)$ received fixed doses of sulphasalazine or 5-aminosalicylic acid (median $3 \mathrm{~g} /$ day, range 1-3 g/day) alone or in combination with corticosteroids. All patients had active $\mathrm{CD}$ according to the Crohn's Disease Activity Index ${ }^{12}$ (median 268, range 151-540). The median plasma orosomucoid concentration was $35 \mu \mathrm{mol} / \mathrm{l}$ (range $15-82 \mu \mathrm{mol} / \mathrm{l}$ ); reference interval 11-30 $\mu \mathrm{mol} / \mathrm{l}$. There were no significant differences in baseline characteristics between patients treated with cyclosporin and those receiving placebo. The patients were studied before treatment, after two weeks of treatment, and then monthly and were classified as either improved or not improved according to a modified clinical grading score. ${ }^{713}$

Nineteen healthy subjects (median age 38 years, range 28-61 years) served as controls for the IL-2 assay and another 21 healthy subjects (median age 37 years, range 21-60 years) served as controls for the sIL-2R assay.

ELISA

Serum and heparin-stabilised plasma samples were stored at $-80^{\circ} \mathrm{C}$ until use. The ELISAs were performed in one setting at the end of the study using previously unthawed samples. Serial samples from one patient were analysed on the same ELISA plate.

IL-2 ASSAY

Plasma IL-2 concentrations were determined by 
solid phase, triple layer ELISA (Intertest-2, Genzyme Corp, Boston MA). Fibrin was removed by incubation of $\mathrm{CaCl}_{2}$ and plasma $1: 9$ for two hours at $37^{\circ} \mathrm{C}$ followed by centrifugation. Plasma samples were diluted $1: 2$ by phosphate buffered saline before assay. Firstly, a specific monoclonal anti-IL-2 antibody was absorbed onto 96-well polystyrene microtitre plates by incubation at $37^{\circ} \mathrm{C}$ for 18 hours. Plasma samples were added in duplicates together with known recombinant IL-2 standards for each plate and incubation was continued for 18 hours. Secondly, a polyvalent rabbit anti-IL-2 antibody recognising a different epitope on the human IL-2 was added and bound to captured IL-2 in the solid phase. Thirdly, an alkaline phosphateconjugated goat antirabbit immunoglobulin antibody was added. A substrate solution (paranitrophenyl phosphate) was finally added, and the colour reaction was read against a substrate blank using a microtitre ELISA reader (Titertek, Flow Laboratories, USA). The amount of IL-2 in each sample was derived from the optical density curve of the known standards. Previous studies have shown that in the case of fresh recombinant IL-2, 1 ELISA unit (equivalent to $0.33 \mathrm{ng}$ ) corresponds to about $0 \cdot 8-1 \cdot 2$ units $(0 \cdot 27-0.4 \mathrm{ng})$ defined by the CTLL bioassay. ${ }^{14}$ Reproducibility in our laboratory was within $10 \%$.

\section{SIL-2R ASSAY}

Serum sIL-2R concentrations were determined by solid phase, double layer ELISA ( $T$ Cell Sciences Inc, Cambridge MA) according to Rubin et al. ${ }^{8}$ Firstly, a specific monoclonal antibody recognising the Tac-epitope on the human IL-2R ${ }^{15}$ was absorbed onto 96-well microtitre plates at $4^{\circ} \mathrm{C}$ for 18 hours. Serum samples were added in duplicates together with known IL-2R standards for each plate and incubated at $37^{\circ} \mathrm{C}$ for two hours. The second antibody layer consisted of a specific horseradish peroxidase-conjugated monoclonal antibody $(7 \mathrm{G} 7 / \mathrm{B} 6)^{16}$ that binds to an epitope on the human IL-2R distinct from those of anti-Tac and IL-2, and incubation was continued for two hours. A substrate solution (o-phenylenediamine) was added and the colour reaction was read against substrate blank using the ELISA reader. The amount of sIL-2R in each sample was derived from the optical density curve of the known standards. Previous studies have shown that 1 ELISA unit sIL-2R is equivalent to about 0.3 pg purified receptor. ${ }^{17}$ The reproducibility in our laboratory was again within $10 \%$.

\section{STATISTICS}

Unpaired observations were tested by the Kruskal-Wallis and the Mann-Whitney test; paired observations were tested by Page's test for trend. Two sided tests were used (except for Page's test, which is one tailed). For Page's test, single missing values were replaced by the nearest or the mean of nearest values. Values of premature withdrawals were carried over to later time points of evaluation. The level of significance was $\mathrm{p}<0.05$.

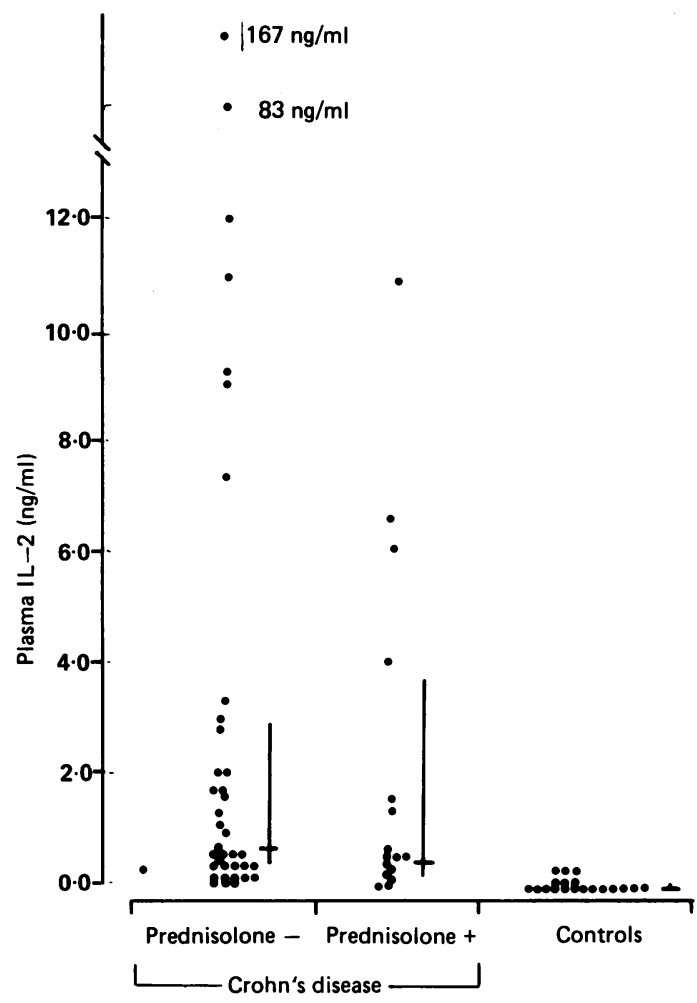

Figure 1: Plasma interleukin-2 (IL-2) concentrations in 53 patients with Crohn's disease and 19 matched controls. Patients are stratified according to baseline treatment with prednisolone $(+/-)$. Bars indicate medians and the 25 th and 75th percentiles ( $p<0.00001$, Kruskal-Wallis test).

\section{Results}

The baseline median ( $25-75 \%$ range) plasma IL2 concentration was $0.6 \mathrm{ng} / \mathrm{ml}(0.3-2.85 \mathrm{ng} / \mathrm{ml})$ in patients not receiving prednisolone, $0.5 \mathrm{ng} / \mathrm{ml}$ $(0.23-3.4 \mathrm{ng} / \mathrm{ml})$ in patients who did receive prednisolone (not significant), and $0 \mathrm{ng} / \mathrm{ml}$ $(0-0.07 \mathrm{ng} / \mathrm{ml})$ in control subjects $(\mathrm{p}<0.00001)$ (Fig 1). There was no correlation between plasma IL-2 levels and plasma orosomucoid levels or Crohn's Disease Activity Index values. Plasma IL-2 concentrations above the total range observed in healthy controls $(0.3 \mathrm{ng} / \mathrm{ml})$ were seen in $66 \%$ of the patients, and very high concentrations in two patients.

The corresponding median serum sIL-2R concentrations were $747 \mathrm{U} / \mathrm{ml}(580-1287 \mathrm{U} / \mathrm{ml})$ and $540 \mathrm{U} / \mathrm{ml}(422-616 \mathrm{U} / \mathrm{ml})$ in $\mathrm{CD}$ patients $(p=0.006)$ without and with steroid medication respectively, and $320 \mathrm{U} / \mathrm{ml}(268-406 \mathrm{U} / \mathrm{ml})$ in control subjects $(\mathrm{p}<0.00001)($ Fig 2$)$. There was a significant correlation between serum sIL-2R and plasma orosomucoid concentrations $(r(S)=$ $0.55, p=0.00008)$, but not between sIL-2R concentrations and Crohn's Disease Activity Index values. By contrast, significant correlations were found among changes in sIL-2R concentrations and grading score totals, which measured changes in disease activity, at month 3 $(r(S)=0.429, p=0.01)$ as well as at earlier points of evaluation. Increased serum sIL-2R concentrations $(>470 \mathrm{U} / \mathrm{ml})$ were seen in $81 \%$ of the patients. There was no correlation between plasma IL-2 and serum IL-2R concentrations.

\section{EFFECTS OF TREATMENT}

No significant changes were observed in plasma IL-2 either within or between treatment groups 
TABLE I Interleukin-2 concentrations ( $\mathrm{ng} / \mathrm{ml})$ in 61 patients with Crohn's disease during a placebo controlled trial of cyclosporin treatment (median and $25-75 \%$ range)

\begin{tabular}{llll}
\hline & Month & \\
\cline { 2 - 4 } Groups & 0 & 3 & No of patients \\
\hline Cyclosporin & $0 \cdot 5(0 \cdot 2-1 \cdot 9)$ & $0 \cdot 5(0 \cdot 2-2 \cdot 1)$ & 32 \\
Placebo & $1 \cdot 0(0 \cdot 4-6 \cdot 3)$ & $1 \cdot 0(0 \cdot 3-6 \cdot 2)$ & 29 \\
Improved with cyclosporin & & $0 \cdot 5(0 \cdot 1-1 \cdot 0)$ & 19 \\
Not improved with cyclosporin & & $0 \cdot 8(0 \cdot 3-3 \cdot 7)$ & 13 \\
Improved with placebo & $0 \cdot 9(0 \cdot 3-7 \cdot 4)$ & 9 \\
Not improved with placebo & & $1 \cdot 4(0 \cdot 3-7 \cdot 6)$ & 20 \\
\hline
\end{tabular}

All comparisons: not significant.

(Table I). In addition to the two patients with a high baseline plasma IL-2, high concentrations were encountered again during treatment in three patients. These five patients showed no specific features apart from raised serum sIL-2R $(970-3019 \mathrm{U} / \mathrm{ml})$ and plasma orosomucoid (32-78 $\mu \mathrm{mol} / \mathrm{l})$ concentrations.

By contrast, median serum sIL-2R concentrations were significantly lower in the cyclosporin group compared with the placebo group from week two and later on (Table II). Stratification of patients according to treatment and clinical outcome showed a highly significant trend towards a decrease in sIL-2R, but only in patients who improved with cyclosporin treatment (Table II).

\section{Discussion}

This study showed high circulating concentrations of IL-2 and sIL-2R in patients with chronic active $C D$ compared with healthy control subjects. Although the majority of the CD patients showed only slightly raised plasma IL-2 concentrations, the fact that about two thirds of these values were above the range found in healthy subjects (Fig 1) seems to contrast with previous in vitro findings. Here decreased or absent IL-2 production by blood or mucosal mononuclear cells, or both, have been found in active inflammatory bowel disease (IBD) using biological assays. ${ }^{2-4}$ It has also been suggested that an insufficiency of IL-2 may hamper the development of a normal immune response, perhaps contributing to the chronicity of IBD. ${ }^{4}$ Mucosal lymphocytes, however, produce high concentrations of IL-2 after challenge with a strong antigen-unspecific stimulus, such as combined phorbol-12-myristate-13-acetate and phytohaemagglutinin. ${ }^{4}$ Moreover, production of IL -2 by blood mononuclear cells is normal in

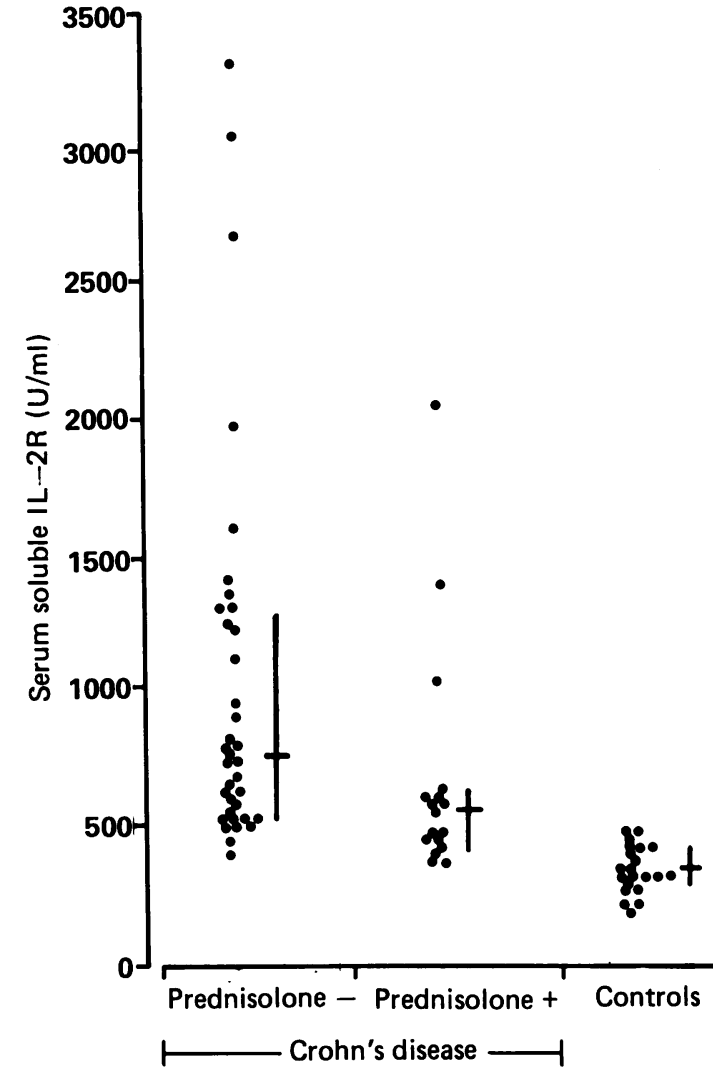

Figure 2: Serum soluble interleukin-2 receptor concentrations (sIL-2R) in 53 patients with Crohn's disease and 21 matched controls. Patients are stratified according to baseline treatment with prednisolone $(+1-)$. Bars indicate medians and the 25 th and 75th percentiles ( $p<0.00001$, Kruskal-Wallis test).

patients with inactive IBD, which suggests that a deficiency of this lymphokine is not a primary factor in IBD. ${ }^{18}$ This assumption is supported by the fact that cyclosporin, a potent inhibitor of IL-2 production and T cells, ${ }^{6}$ has a beneficial therapeutic effect in chronic active $\mathrm{CD}$. $^{7}$

It was Rubin $e t a l^{8}$ who showed that activated peripheral $\mathrm{T}$ cells ${ }^{19}$ released/shed a soluble form of cellular IL-2R in vitro. Increased serum or plasma sIL-2R concentrations have subsequently been shown by ELISA in clinical conditions characterised by enhanced $T$ cell activity in vivo, such as kidney and liver transplant rejection, ${ }^{9-11}$ $\mathrm{T}$ cell leukaemia, ${ }^{20}$ systemic lupus erythematosus, ${ }^{21}$ and viral infections of the liver. ${ }^{22}$ The present finding of significantly increased serum sIL-2R concentrations in patients with $C D$ suggests that $T$ cells also are activated in this condition. Moreover, this result is in good agree-

TABLE II Serum sIL-2R concentrations $(\mathrm{U} / \mathrm{ml})$ in 59 patients with Crohn's disease during a placebo controlled trial of cyclosporin treatment (median and $25-75 \%$ range)

\begin{tabular}{|c|c|c|c|c|c|c|c|}
\hline \multirow[b]{2}{*}{ Groups } & \multicolumn{7}{|l|}{ Month } \\
\hline & 0 & 0.5 & 1 & 2 & 3 & $\begin{array}{l}\text { No of } \\
\text { patients }\end{array}$ & $p \dagger$ \\
\hline $\begin{array}{l}\text { Cyclosporin } \\
\text { Placebo } \\
\mathrm{p}^{\star}\end{array}$ & $\begin{array}{l}603(501-885) \\
792(586-1388) \\
\text { NS }(0 \cdot 058)\end{array}$ & $\begin{array}{l}563(460-852) \\
974(614-1600) \\
0.002\end{array}$ & $\begin{array}{l}597(416-792) \\
903(561-1442) \\
0.002\end{array}$ & $\begin{array}{l}534(416-788) \\
1042(654-1590) \\
0 \cdot 0003\end{array}$ & $\begin{array}{l}566(420-828) \\
962(654-1442) \\
0.005\end{array}$ & $\begin{array}{l}32 \\
27\end{array}$ & $\begin{array}{l}\text { NS }(0.06) \\
\text { NS }\end{array}$ \\
\hline \multicolumn{2}{|c|}{$\begin{array}{l}\text { Improved with cyclosporin } \\
\text { Not improved with cyclosporin } \\
\mathrm{p}^{\star} \\
\text { Improved with placebo } \\
\text { Not improved with placebo } \\
\mathrm{p}^{\star}\end{array}$} & $\begin{array}{l}558(460-844) \\
569(465-912) \\
\text { NS } \\
966(562-1602) \\
974(645-1665) \\
\text { NS }\end{array}$ & $\begin{array}{l}580(413-766) \\
616(411-801) \\
\text { NS } \\
1037(749-1675) \\
819(496-1242) \\
\text { NS }\end{array}$ & $\begin{array}{l}479(358-804) \\
672(542-798) \\
\text { NS } \\
1245(899-1727) \\
764(575-1442) \\
\text { NS }\end{array}$ & $\begin{array}{l}440(400-668) \\
801(534-1067) \\
0.003 \\
1175(1004-1565) \\
816(511-1337) \\
\text { NS }\end{array}$ & $\begin{array}{r}19 \\
13 \\
9 \\
9 \\
18\end{array}$ & $\begin{array}{l}0.006 \\
\text { NS } \\
\text { NS } \\
\text { NS }\end{array}$ \\
\hline
\end{tabular}

^ Mann-Whitney test for unpaired data.

Page's test for trend towards a decrease at month 3 (one tailed).

NS = not significant 
ment with previous studies showing an increased $T$ cell surface expression of early activation markers such as 4F2, OKT9, and HLA-DR as well as IL-2R in CD. ${ }^{2324}$

The dimeric high affinity receptor complex that mediates the proliferative signal for $T$ cells consists of an intermediate affinity beta chain and a low affinity alpha chain, called Tac. ${ }^{25-28}$ The density of Tac receptors increases during immune stimulation and may function as a down regulator of the $T$ cell response by covering the high affinity binding sites and by trapping free IL-2. ${ }^{29}$ Since sIL-2R binds free IL-2, the latter function may also be operative in vivo. ${ }^{30}$

This study suggests that serum sIL-2R may be a marker of disease activity in $\mathrm{CD}$, in contrast to plasma IL-2. The finding, however, of a significantly decreased median serum sIL-2R concentration only in patients who improved with cyclosporin treatment at month 3 as well as a strong significant trend throughout the treatment period (Table II) may be of even greater interest. A simple explanation would be that serum sIL-2R is a marker of an acute-phase response, but a tendency towards an increase was seen in patients who improved with placebo (Table II). Another possibility is that suppression of IL-2 production itself leads to decreased sIL-2R release since the ligand regulates the expression of IL-2R. ${ }^{29}$ The finding, however, of unchanged serum sIL-2R in patients who failed with cyclosporin makes this less likely. The effect of cyclosporin on IL-2R expression is obscure. Conflicting results have been obtained in vitro, and the expression seems to depend on the type of stimulation, ${ }^{6}$ suggesting that cyclosporin exerts no direct effect on IL-2R expression.

Finally, the decline in serum sIL-2R concentrations in patients who improved with cyclosporin treatment may reflect a drug induced diminished $\mathrm{T}$ cell activation. Hence Baker and Jewell ${ }^{31}$ have recently reported that cyclosporin clears the expression of HLA-DR antigens on colonic epithelial cells, normally for responsible activation of $\mathrm{T}$-helper cells. These findings are in keeping with the prevailing concept that activated immunological effector mechanisms occur in $\mathrm{CD}$ as a result of an increased antigen stimulation. ${ }^{5}$ But, owing to the considerable variation in sIL-2R suppression, this measure cannot be used to monitor cyclosporin treatment in individual patients.

Taken together the results suggest that the IL-2 dependent pathway of immune activation is upregulated in vivo in $\mathrm{CD}$ and that cyclosporin treatment may interfere with this process. Further studies are, however, needed to detail the effects of cyclosporin in CD.

We thank the following physicians who participated in the Danish-Italian Crohn's Disease Study Group for their collaboration: V Binder, P Riis, Department of Internal Medicine and Gastroenterology C, Herlev University Hospital; L Freund, S Nørby Rasmussen, Department of Internal Medicine and Gastroenterology, Aalborg Hospital; K Lauritsen, O Schaffalitzky de Muckadell, Department of Internal Medicine and Gastroenterology S, Odense University Hospital; A Malchow-Møller, O Østergaard Thomsen, U Tage-Jensen, Department of Interna Medicine and Gastroenterology P, State University Hospital Copenhagen; P Bianchi, MC Campanini, T Ranzi, F Quarto d Palo, Department of Internal Medicine and Gastroenterology, Ospedale Maggiore, Milan.
We thank B Deibjerg and L Persson, Laboratory of Medical Gastroenterology 5403, Herlev University Hospital, and A Ambjørnsen, Laboratory of Medical Immunology 7544, Copenhagen University Hospital, for their technical assistance; and N Børresen, Sandoz Ltd, Copenhagen, Leo Pharmaceutical ComBørresen, Sandoz Ltd, Copenhagen, Leo Pharmaceutical Com-
any, and the Ovesen Foundation, Denmark, for financial support. J B and N T hold research fellowships granted by the University of Copenhagen, Faculty of Medicine.

1 Cantrell DA, Smith KA. The interleukin-2 T-cell system. Science 1984; 224: 1312-6.

2 Ebert EC, Wright SC, Lipshutz WH, Hauptman SP. T-cell abnormalities in inflammatory bowel diseases are mediated by interlen.

3 Myura M, Hiwatshi N. Cytokine production in inflammatory bowel disease. F Clin Lab Immunol 1985; 18: 81-6.

4 Fiocchi CF, Hilfiker ML, Youngman KR, Doerder NC, Finke JH. Interleukin 2 activity of human intestinal mucosa mononuclear cells. Gastroenterology 1984; 86: 734-42.

5 Jewell DP, Patel C.. Immunology of inflammatory bowel disease. Scand $\mathcal{F}$ Gastroenterol 1985; 114 [suppl]: 119-26.

6 Hess AF, Colombani PM. Mechanism of action: in vitro studies. In: Borel J, ed. Cyclosporin. Basel: Karger, 1986: 198-221.

7 Brynskov J, Freund L, Nørby Rasmussen S, et al. A placebocontrolled, double-blind, randomized trial of cyclosporine therapy in active chronic Crohn's disease. $N$ Engl f Med therapy in active

8 Rubin LA, Kurman CC, Fritz ME, et al. Soluble interleukin 2 receptors are released from activated human lymphoid cells in vitro. F Immunol 1985; 135: 3172-7.

9 Cornaby A, Simpson MA, Vann Rice R, Dempsey RA Madras PN, Monaco AP. Interleukin-2 production in plasma and urme, plasma interleukin -2 receptor levels, and urine cytology as a means of monitoring renal allograft recipients. Transp Proc 1988; 20 [suppl]: 108-10.

10 Colvin RB, Fuller TC, MacKeen L, Kung PC, Ip SH, Cosimi AB. Plasma interleukin 2 receptor levels in renal allograft recipients. Clin Immunol Immunopathol 1987; 43: 273-6.

11 Adams DH, Hubscher SG, Wang L, Elias E. Soluble interleukin-2 receptors in serum and bile of liver transplant patients. Lancet 1989; i: 469-71.

12 Best WR, Becktel JM, Singleton JW, Kern F Jr. Development of a Crohn's disease activity index. National cooperative of a Crohn's disease activity index. National cooperative

13 Brynskov J, Binder V, Riis P, et al. Low-dose cyclosporin for Crohn's disease: implications for clinical trials. Alimen Pharmacol Therap 1989; 3: 135-42.

14 Huang Y-P, Perrin LC, Miescher PA, Zubler RH. Correlation of $\mathrm{T}$ and $\mathrm{B}$ cell activities in vitro and serum $\mathrm{IL}-2$ levels in systemic lupus erythematosus. $\mathcal{F}$ Immunol 1988; 141 827-33.

15 Uchiyama T, Broder SA, Waldman TA. A monoclonal antibody reactive with activated and functionally mature human T-cells. F Immunol 1981; 126: 1393-7.

16 Rubin LA, Kurman CC, Biddison WE, Goldman NE, Nelson DL. A monoclonal antibody, $7 \mathrm{G} 7 / \mathrm{B} 6$, binds to an epitope on the human interleukin-2 (IL-2) receptor that is distinct from that recognized by $\mathrm{IL}-2$ or anti-Tac. Hybridoma 1985 ; 4:91-102.

17 Hakimi J, Seals C, Anderson LE, et al. Biochemical and functional analysis of a soluble human interleukin-2 recepto produced in rodent cells. $\mathcal{F}$ Biol Chem 1987; 262: 17336-41.

18 Ming RH, Atluru D, Spellman CW, Imir T, Goodwin JS, Strickland RG. Peripheral blood mononuclear-cel interleukin-2 production, receptor generation and lymphokine-activated cytotoxicity in inflammatory bowel disease. F Clin Immunol 1987; 7: 59-63.

19 Nelson DL, Rubin LA, Kurman CC, Fritz ME, Boutin B. An analysis of the cellular requirements for the production of soluble interleukin-2 receptors in vivo. $\mathcal{F}$ Clin Immunol 1986; 6: 114-9.

20 Marcon L, Fritz ME, Kurman CC, Jensen JC, Nelson DL. Soluble Tac peptide is present in the urine of normal individuals and at elevated levels in patients with adult $\mathrm{T}$ cell leukaemia (ATL). Clin Exp Immunol 1988; 73: 29-33.

21 Wolf RE, Brelsford WG. Soluble interleukin-2 receptors in systemic lupus erythematosus. Arthritis Rheum 1988; 31 $729-35$

22 Yamaguchi S, Onji $M$, Ohth $Y$. Increased serum soluble interleukin 2 receptor levels in patients with viral live diseases. Hepatogastroenterology $1988 ; 35: 245-8$.

23 Pallone F, Fais S, Squarcia O, Biancone L, Pozzilli P Bolrivant M. Activation of peripheral blood and intestinal lamina propria lymphocytes in Crohn's disease. In vivo state of activation and in vitro response to stimulation as defined of activation and in vitro response to stimulation as defined by the expr.

24 Raedler A, Fraenkel S, Klose G, Seyfarth K, Thiele HG. Involvement of the immune system in the pathogenesis of Involvement of the immune system in the pathog
Crohn's disease. Gastroenterology 1985; 88:978-83.

25 Tsudo M, Kozak RW, Goldman CK, Waldman TA. Demonstration of a non-Tac peptide that binds interleukin 2: a potential participant in multichain interleukin 2 recepto complex. Proc Natl Acad Sci USA 1986; 83: 9694-8.

26 Sharon M, Klausner RD, Cullen BR, Chizzonite R, Leonard WJ. Novel interleukin -2 receptor subunit detected by crosslinking under high-affinity conditions. Science 1986; 234 859-63.

27 Teshigawara $\mathrm{K}$, Wang $\mathrm{H}$, Kato $\mathrm{K}$, Smith KA. Interleukin 2 high-affinity receptor expression requires two distinct binding proteins. $\mathcal{F} \operatorname{Exp} M e d 1986 ; 165: 223-38$. 
28 Fujii M, Sogamura K, Sabno K, Nakai M, Sugita K, Hinuma $Y$. High-affinity receptor-mediated internalization and degradation of interleukin 2 in human T-cells. $\mathcal{F}$ Exp Med 1986; 163: $550-62$.

29 Smith KA, Cantrell DA. Interleukin 2 regulates its own receptor. Proc Natl Acad Sci USA 1985; 82: 864-8.
30 Rubin LA, Jay G, Nelson DL. The released interleukin 2 receptor binds interleukin 2 efficiently. $\mathcal{F}$ Immunol 1986; 137: $3841-4$

31 Baker K, Jewell DP. Cyclosporin for the treatment of severe inflammatory bowel disease. Aliment Pharmacol Therap 1989; 3: 143-9.
Correction Abnormal gastric adaptive relaxation in patients with gastrooesophageal reflux by M N Hartley, S J Walker, C R Mackie. May 1990 issue, pp 500-3. In this article several lines of text in the Methods section were transposed. The corrected text appears below.

\section{Methods}

SUBJECTS

Fifteen normal healthy volunteers were studied. These were 13 men and two women, with a median age of 30 years (range 22-41) and a median body weight of $70 \mathrm{~kg}$ (range $50-79$ ) kg. Twelve patients with symptomatic gastrooesophageal reflux were studied. They were eight men and four women, with a median age of 48 years (range 23-65) and a median body weight of $77 \mathrm{~kg}$ (range $60-92 \mathrm{~kg}$ ). All subjects in the control group were asymptomatic. Among patients in the reflux group, eight were complaining of regurgitation, 11 of heartburn, and four of dysphagia.

The presence of pathological gastrooesophageal reflux was confirmed in all patients in the reflux group by 24 hour ambulatory oesophageal $\mathrm{pH}$ monitoring. Pathological gastrooesophageal reflux was defined as the presence of one or more of the following criteria: total reflux time greater than $6 \%$, erect reflux time greater than $8 \%$, supine reflux time greater than $2 \%$; more than two reflux episodes longer than five minutes. A reflux episode was defined as a drop in $\mathrm{pH}$ to 4 or less.

Endoscopy showed macroscopic oesophagitis in seven patients, associated with a hiatus hernia in four patients. Five patients had no abnormality at endoscopy. None of the subjects in the control group was on any medication and all medication was withheld for 12 hours before the study in all patients. After an overnight fast, subjects swallowed, via the nose a 10F Ryle's tube with a collapsed, plastic bag $(800 \mathrm{ml})$ sealed over the end, the side holes of the tube being within the bag. Within the lumen of the tube, positioned near its tip, was a pressure microtransducer (Gaeltec, Dingwall, Rosshire, Scotland) which was calibrated against a water manometer to provide a full scale deflection of
$50 \mathrm{~cm}$ water pressure. The transducer was interfaced with an amplifier and pen recorder (Gould Electronics Limited, Coventry, England) to record pressure changes against time. The bag was positioned manometrically in the corpus-fundus region of the stomach. A baseline recording was obtained during a 15 minute rest period. Air from a compressed air cylinder (British Oxygen Company, Guildford, Surrey, England) was delivered at a constant rate through an air flow meter and a safety valve to the Ryle's tube. This constant flow of air was used to distend the bag at a rate of $15 \mathrm{ml} /$ second for 30 seconds during which the pressure rise was recorded (dynamic recording). The recording was continued at this end volume for a further 150 seconds (static recording). The air was then aspirated with a syringe and the volume noted. This procedure was repeated at 15 minute intervals to provide four recordings for each subject, two each with the subjects sitting and supine. For each recording a dynamic pressure index was derived from the area under the curve during distension and a static pressure index was derived similarly, during the postinsufflation period of 150 seconds. These measurements were ascribed units in $\mathrm{cm} \mathrm{H}_{2} \mathrm{O}$ (Fig 1). A dynamic and static pressure index was derived for each subject, sitting and supine, based on the mean of the two values for each. These data were used to assess the effect of posture on gastric adaptive relaxation and also to compare the dynamic and static methods. Statistical analysis was by the Wilcoxon's signed-rank sum test for the former and the Mann Witney U test for the latter. The reproducibility of the technique was assessed in duplicate studies on separate days among eight healthy volunteers, seven of whom were drawn from the control group for this study. The eighth subject gave a history of reflux symptoms and was therefore excluded from the control group for the main study. Reproducibility was expressed as the Spearman rank correlation coefficient calculated from the pressure indices obtained from paired studies. Finally, in view of the differences in ages and body weights between the two groups, a multiple regression model was created to see if there was any effect of these two variables on pressure index (Statistical Analysis System package, SAS Institute Inc, NC 27511, USA). 